\title{
SHIP CREW MANAGEMENT IN EMERGENCY ON THE EXAMPLE OF A SHIPPING COMPANY
}

\section{УПРАВЛІННЯ ЕКІПАЖЕМ СУДНА В НАДЗВИЧАЙНОЇ СИТУАЦІЇ НА ПРИКЛАДІ СУДНОПЛАВНОЇ КОМПАНІЇ}

\author{
V.Y. Shemonayev, PhD, associate professor, I.L. Surinov, PhD student, assistant \\ В.Ю. Шемонаєв, к.ю.н., дочент, І. Л. Сурінов, аспірант, асистент кафедри \\ National University «Odessa Maritime Academy», Ukraine \\ Нациинальный университет «Одесская морская академия», Украина
}

\begin{abstract}
Risk is like queering someone or something valued to an unknown or anticipated danger, harm, or loss. Even though there is no such universally accepted general definition of risk, but one commonly applied and authoritative resolution in most industrial contexts defines risk as " $A$ combination of the probability, or frequency, of occurrence of a defined hazard and the magnitude of the consequences of the occurrence."

According to the International Maritime Organization (IMO), risk is the "combination of the frequency and the severity of the consequence", thereby articulates two components of the likelihood of occurrence and the probability of severity of the (un)predictable consequences.

"Safety management objectives of the company should establish safeguards against all identified risks" so has been stated in the paragraph 1.2.2.2 of the ISM Code (International Safety Management Code). However, this does not determine any particular approach to the risk management theory, and it is for the company itself to choose methods appropriate in accordance with its organizational structure, its ships and trades. The methods could vary accordingly but how ever more or less formal they are, they should be well organized and planned if assessment and responses are meant to be completed and act effectively.
\end{abstract}

Keywords: accident, risk, world shipping, vessel, crew, safety management, risk management theory.

\section{Постановка проблеми в загальному вигляді та її зв'язок 3 важливими науковими та практичними задачами}

Початок XXI століття характеризується наявністю великого спектра концепцій і теорій, що визначають розвиток управління персоналом, які розрізняються позиціями відносно ролі та значення людини в компанії. В результате склалася парадоксальна ситуація: з одного боку, $\epsilon$ досить велика різноманітність теоретичних поглядів на розвиток управління персоналом як системи наукових знань, а з іншого боку, відсутні методологія та теорія, що розкривають процес розвитку систем управління персоналом, особливо у високотехнологічних та пов'язаних 3 особливими ризиком компаніях, таких, наприклад, як судноплавство, яка органічно вплелася в життя людства. Професія моряка стала по суті масовою, але в той же час вона зберегла всі риси критичних професій, тобто таких, в межах яких людина постійно піддається впливу ряду негативних чинників (стрес-факторів), стійкість до яких не $є$ прерогативою всіх людей - факт, який набирає протиріччя з вимогою забезпечення моряками швидко зростаючого світового флоту.

Формування висококваліфікованих, мотивованих та ефективно працюючих членів екіпажу має на увазі систему управління персоналом, що включає в себе два найважливіших елементи: по-перше, зв'язок перспективних цілей та завдань компанії з інтересами кожного іiі 
співробітника, i, по-друге, зв'язок результатів та безпосередніх цілей кожного окремого екіпажу з інтересами всього персоналу компанії.

\section{Аналіз останніх досягнень та публікацій, в яких розпочато розв'язання даної проблеми та висвітлювання нерозв`язаних раніше частин загальної проблеми}

Розвиток управління персоналом відбувався в останнє десятиліття досить інтенсивно. Розроблено основні положення, що стосуються предмета, цілей, задач та функцій управління ним. Детально описаний зарубіжний досвід та умови його сучасного використання, розроблені механізми та технології управління приватними процесами тощо. Все це дозволяє зробити висновок, що управління персоналом пройшло стадію інституалізації, а наявні наукові та практичні напрацювання вимагають узагальнення, систематизації та теоретикометодологічного осмислення на рівні окремих екіпажів та компаній.

Значний внесок у розробку даної проблеми внесли Базаров Т Ю, Веснін В.Р, Волгін Н.А., Грачов М.В, Дятлов В.А., Егоршин А П., Кібанов А.Я, Кулапов М.Н., Лобанов А.А., Маусов Н.К., Матірко В.І, Одегов ЮГ., Половинко ВС, Руденко ГГ., Травін В.В., Шубенкова С.В. та ін., роботи яких стали теоретичного основою досліджень. На формування авторської позиції вплинули праці таких вчених: М. Армстронга, Н. Дилера, Е. Дюркгейма, П. Друкера, Р. Мара, Е Мейо, Т. Петерса, С. Тейлора, Д. Торрінгтона, Л. Холла, А. Файоля, Г. Шмідта та інші., де представлена методологія управління людськими ресурсами як невід'ємної частини управління екіпажем судна та компанією, описані сучасні проблеми їх розвитку та узагальнюється досвід різних організацій з управління персоналом.

\section{Формулювання мети статті (постановка задачі)}

Головного метою цієї роботи є аналіз літературних джерел щодо вирішення наступних завдань:

- дослідження особливостей праці моряків в системі «індивід - група (екіпаж)»;

- визначення напрямків теоретичної та методичної бази розвитку системи управління персоналом компанії, що випливають із філософії тотального управління якістю;

- виявлення тенденцій та закономірностей трансформації основних елементів системи управління персоналом під впливом об'єкта дослідження;

- дослідження особливостей сучасної кадрової політики;

- виявлення і класифікація факторів, що впливають на формування та розвиток компетентності персоналу, визначення її впливу на процес управління ним.

\section{Виклад матеріалу дослідження з обгрунтуванням отриманих наукових результатів}

У практичній діяльності Капітану дуже важливо знати діапазон психофізіологічних можливостей екіпажу, на основі яких визначаються заходи відносно підвищення стійкості організму членів екіпажу в екстремальних умовах і намічаються шляхи вдосконалення необхідних професійних якостей [1].

Встановлено, що знання, навички та вміння, сформовані для нормальних умов праці екіпажу, в екстремальних умовах не забезпечують професійну діяльність в рамках продуктивності, ефективності, безпеки. Стійкість інтелектуальної працездатності, рухових навичок залежить від наявності сформованих механізмів стійкості до екстремальних факторів. Таким чином, науково-технічна революція в морському флоті потребує вирішення проблеми підвищення надійності людського фактору (рис. 1). Очевидно, необхідно воєдино зв'язати професійно-психологічний відбір, процеси формування професійних знань, навичок та умінь, динамічного здоров'я та збереження професійного довголіття моряків. 


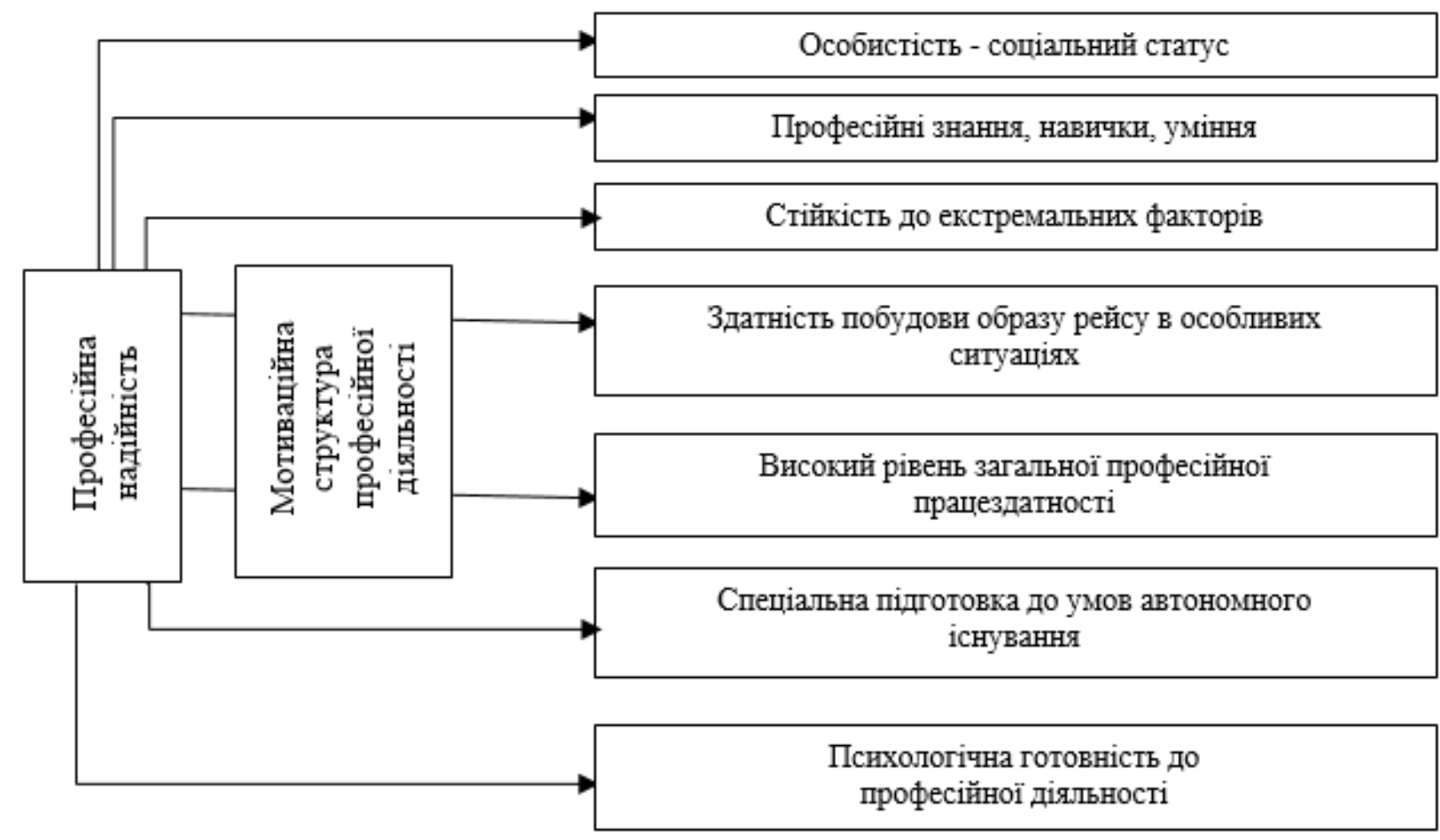

Рис. 1. Складові професійної надійності

Екіпаж є тим життєвим середовищем, в якому відбувається формування особистості кожного його члена, іiі розвиток. Він має складну структуру, яка багато в чому залежить і від об'єктивних чинників, наприклад, типу суден та, відповідно, виду виконуваних рейсів, а також від ряду суб'єктивних (внутрішніх) факторів [2].

У морському флоті в силу специфіки праці моряків та їх високої компетентності переважають змішані групи, в яких переваги формальної групи тісно поєднуються 3 елементами неформальної. Ці групи визначаються як практичні групи. Вони об'єднують професіоналів, пов'язаних між собою неформальними зв'язками та спільним пошуком рішень загальних проблем, тому мають всі ознаки організації, що сама навчається. Практичні групи відрізняються від других неформальних об'єднань слідкуючими ознака:

- наявність «біографії» - неформальні практичні групи складаються та еволюціонують на протязі певного часу;

- наявність загальної місії, тобто члени екіпажу, що входять до нього, керуються інтересами справи, вони об'єднуються для досягнення загальної мети;

- ефект спільного навчання.

Управління персоналом на морському флоті - це цілеспрямований вплив передбачених кадровою політикою мір на екіпаж та окремих членів екіпажу шляхом використання сукупності прийомів, в основі яких лежить знання психології, етики спілкування, соціології, економіки та права. В сучасних умовах управління персоналом розширює коло своїх функцій та від чисто кадрових питань переходить до розробки систем стимулювання трудової діяльності, управління професійним просуванням, попередження конфліктів, вивченню ринку трудових ресурсів тощо.

Ефективність управління персоналом визначається здатністю менеджменту вибирати такі методи і підходи, які в більшій мірі відповідають стратегії та умовам діяльності компанії. Сьогодні - це управління результативністю, яке передбачає серйозні зміни всіх систем управління компанією, використання як жорстких, так і м'яких підходів до управління персоналом, що дозволяє досягти більшої результативності моряків, підрозділів та компанії в цілому. Виходячи з наявності в структурі судноплавної компанії різних категорій персоналу та враховуючи специфіку роботи екіпажів морських суден необхідно використовувати м'який підхід (рис. 2) до управління персоналом, з виділенням трьох основних напрямків:

- акцент в управлінні на групову роботу; 
- управління знаннями та прищеплення групам свідомості організації, що самонавчається;

- формування та розвиток організаційної культури.

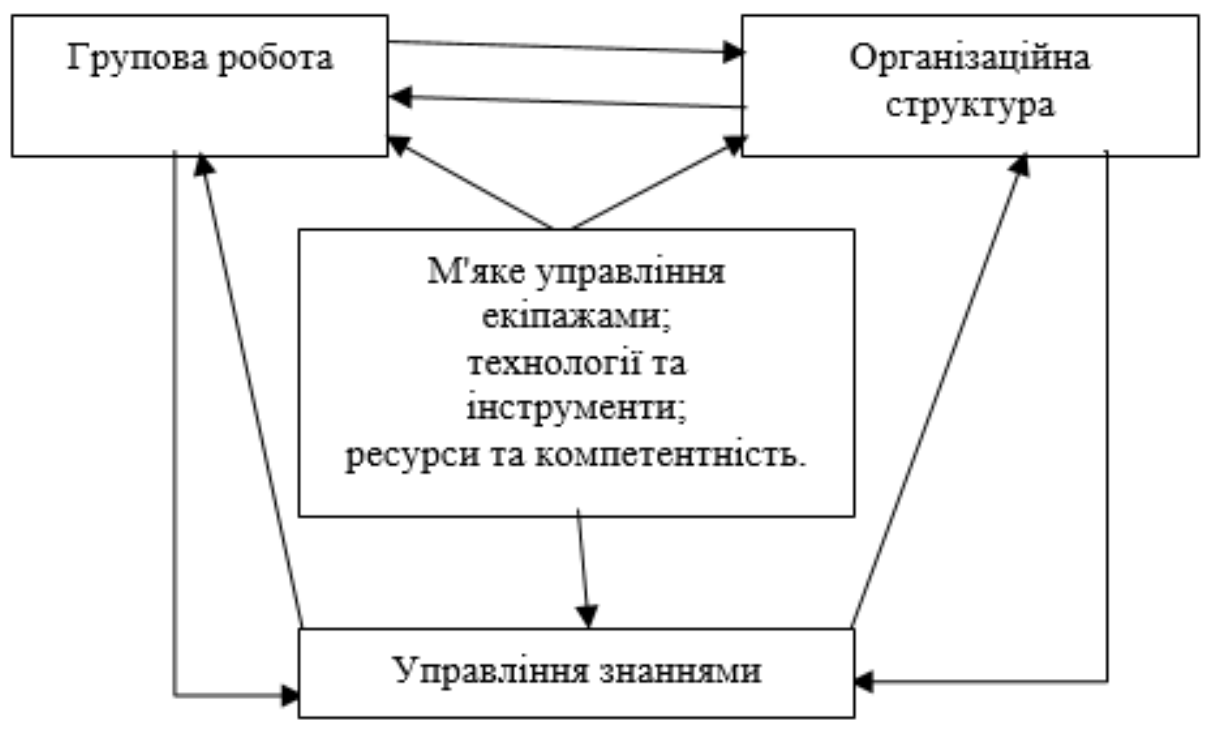

Рис. 2. М'який підхід до управління персоналом

Якщо суть жорсткого підходу до управління людськими ресурсами грунтується на побудові та функціонуванні організаційних систем, що діють незалежно від так званого «людського чинника», то м'яких підхід полягає в переході від роботи групами до групової роботи, що дозволяє досягти синергетичного ефекту від спільної діяльності людей.

Необхідною умовою, що забезпечує розвиток управління персоналом, є формування компетентності персоналу всередині фірми, що дозволяє перетворити стратегічні цілі бізнесу в моделі ефективної поведінки працівників компанії. Для того щоб розвивати корпоративну компетенцію необхідно, перш за все, навчати персонал, використовуючи різні курси підвищення кваліфікації, тренінги та ділові ігри, при цьому кожен працівник, якщо він досить добре розвинутий, може підібрати вид тренінгу, який підходить саме йому. Необхідно регулярно перевіряти відповідність досвідченості, кваліфікації, знань та навичок персоналу потребам компанії. Подібний аналіз повинен проводитись спільно з перевірками наявності необхідних ресурсів та фінансування, 3 урахуванням очікуваних в майбутньому потреб компанії та іiі клієнтів. Аналіз повинен сприяти розробці цільових програм підготовки персоналу та впровадження ефективних процесів відбору та найму співробітників.

Компетентність визначається як набір знань та навичок, необхідних працівникові для виконання покладених на нього функцій та завдань, здатність застосовувати їх на практиці, для ефективного та кваліфікованого виконання роботи, 3 досягненням при цьому встановленого стандарту. Менеджмент повинен гарантувати, що компетентність, яка необхідна для ефективної та результативної роботи організації, $є$ в наявності. 3 цією метою він повинен проводити аналіз поточних та очікуваних потреб відносно компетентності, а також порівнювати ii 3 компетентністю, вже присутньої в компанії. У цьому контексті компетентність - це здібності, навички та знання, що здобуваються або удосконалюються за допомогою розвиваючих робіт (тренінги, інструктаж, співпраця, самоосвіта та ін.).

Управління компетентністю - те саме управлінське нововведення, яке дасть новий стимул до розвитку, до переходу від управління функціями до управління процесами, до збільшенню дійсних «унікальностей» компанії (рис. 3). 


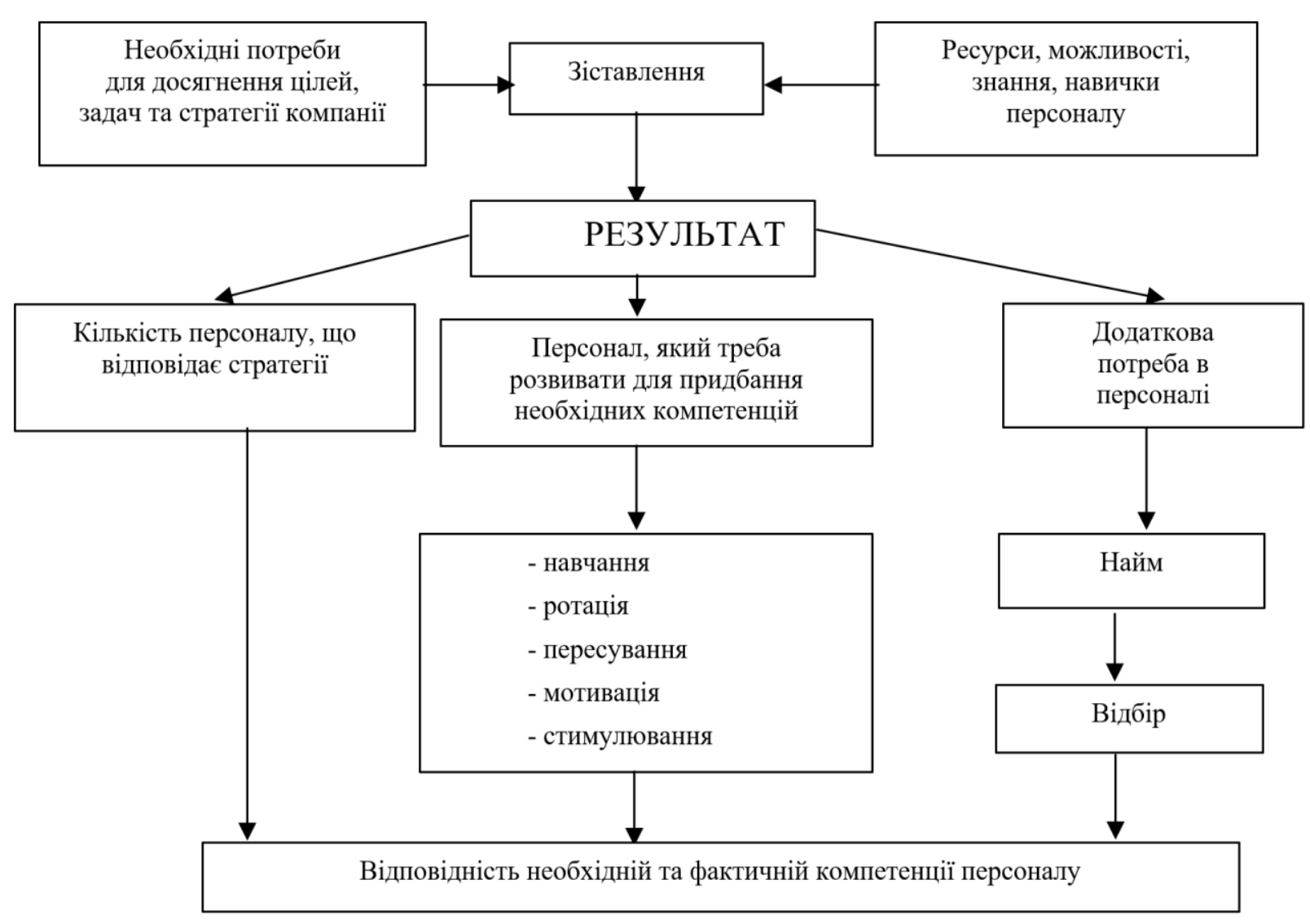

Рис. 3. Управління компетентністю персоналу на рівні компанії

Ефективність функціонування системи управління персоналом, перш за все, залежить від раціонального використання та розвитку людських ресурсів. У процвітаючих компаніях людина грає ключову роль та розглядається як надбання компанії в конкурентній боротьбі, для якого треба створювати відповідні умови та мотиви, які сприяють ефективній роботі, тобто своєчасно планувати, організовувати, мотивувати та контролювати його діяльність на підприємстві. Для цього служби управління персоналом розвинених компаній у своїй роботі орієнтуються на такі сучасні методи роботи з персоналом:

- тактика, в рамках якої здійснюється поточна кадрова робота - це, як правило, комплексне дослідження поточного стану та планування потреби в кадрах, тестування, оцінка та відбір персоналу, розробка штатних розкладів, підготовка, перепідготовка, підвищення кваліфікації, поточний облік і контроль (переміщення та звільнення), а також формування i пропаганда організаційних цінностей та виховання на них персоналу;

- стратегія, в основному орієнтована на формування та послідовну реалізацію кадрової політики через погляди, ідеї, вимоги, практичне дослідження основних форм і методів роботи 3 персоналом.

Як показує досвід, сучасні компанії практично не можуть обійтися без спеціальної служби, що займається розробкою, впровадженням, контролем та коригуванням систем управління персоналом, що забезпечує ефективне функціонування та оновлення цих систем в організації. Важливість цього питання багато в чому пов'язана з дисбалансом між застарілою практикою управління кадрами та сучасними, більш жорсткими вимогами бізнес середовища. В умовах високої конкуренції, коли високо зростає роль знань та виникає боротьба за таланти, відбуваються кардинальні зміни в структурах.

XX століття залишило багату спадщину підходів, теорій, точок зору на те, як слід керувати людьми в компаніях, починаючі з наукового менеджменту Ф. Тейлора, включаючи 
концепції людських відношень, теорію людського капіталу, концепції управління персоналом, розвитку людських ресурсів (японські методи), управління людськими ресурсами та багато іншого. Кожен напрямок вніс свій вклад в розуміння та пояснення причин людської поведінки в скарбничку методів управління цією поведінкою.

Одним 3 таких методів стала система тотального менеджменту якості (TQM), яка представляє собою цілісний підхід до управління, що включає в себе широкий діапазон «жорстких» та «м'яких» методів управління, здатних разом трансформувати культуру організації.

Концептуальною засадою (ядром) для формування інтегрованої системи менеджменту якістю персоналу повинна стати система загального управління якістю, яка отримала світове визнання завдяки стандартам ISO серії 9000 та серії 14000. Ефективне впровадження стандартів ISO, що включають як менеджмент якості, так і забезпечення якості, еквівалентно інтеграції TQM в бізнес конкретної компанії. Стандарти ISO не вимагають ніяких додаткових заходів або інвестицій. Ці стандарти можна використовувати як довідкові (еталонні) матеріали для вироблення заходів, що мають відношення, наприклад, до слабких місць, виявлених в процесі оцінки, виконаної на основі критеріїв премії за якістю. Практика довела, шо завжди варто покращувати системність існуючого менеджменту якості в будь-якій компанії та організації, що опираються на систематизовану методологію [5].

При творчому застосуванні стандартів ISO загальноприйняті принципи TQM, такі як вісім принципів управління якістю, та інструментальні засоби ISO можна використовувати природним способом, об'єднуючи їх з конкретними завданнями даної компанії. У боротьбі за конкурентоспроможність шляхом творчого застосування стандартів ISO корисна передбачити реалізацію наступних аспектів:

- досконалість характеристик бізнесу;

- гнучка якість менеджменту та керівництва, замість формального менеджменту якості;

- вивчення досвіду організації, замість безперервного поліпшення;

- системність якості керівництва, замість систем якості;

- принципи і елементи якості керівництва, замість вимог відносно забезпечення якості;

- довгострокові завдання бізнесу, замість мінімальних вимог стандарту;

- творчі й унікальні рішення, замість стереотипних систем;

- внутрішнє самооцінювання характеристик діяльності, замість аудиту та сертифікації систем якості третьою стороною;

- знання, замість тільки реєстрації явних даних та інформації.

Побудова відношень між компанією та моряками базується на основі взаємної зацікавленості в розвитку один одного як потреби та фактору виживання компанії.

Дана обставина дозволяє говорити про те, що управління персоналом в умовах переходу до TQM має бути розвиваючим і протікати в дусі соціального партнерства між працівниками та роботодавцями.

Необхідною умовою, що забезпечує цей розвиток, $є$ внутрішньо фірмове формування компетенції персоналу, що дозволяє перетворити стратегічні цілі бізнесу в модель ефективної поведінки працівників компанії. Необхідно регулярно перевіряти відповідність досвідченості, кваліфікації, знань та навичок персоналу потребам компанії. Це сприятиме розробці цільових програм підготовки екіпажів та впровадження ефективних процесів відбору та найму.

Компанія повинна визначати необхідні компетенції своїх співробітників для кожного виду діяльності та управляти цим процесом, а персонал повинен «набувати» відсутні компетенції та здібності.

Управління компетентністю, представляє процес концентрації зусиль компанії на відтворенні та розвитку конкурентних переваг своїх працівників, це теж саме управлінське нововведення, яке дасть новий стимул до розвитку і переходу від управління функціями до управління процесами, до збільшення дійсних «унікальностей» компанії.

Компанія повинна забезпечити визначення потреб в компетенціях та навчанні, запропонувати відповідні види навчання, періодично контролювати та аналізувати 
ефективність цих заходів та вести відповідні записи про освіту, досвід, навчанні і кваліфікації своїх співробітників.

Компанія повинна аналізувати потребу в розвитку для кожного співробітника. Необхідне навчання повинно ефективно підтримувати та збільшувати здібності і досвід персоналу по розширенню компетенції. Повинні бути запропоновані види навчання з особистого розвитку, використані різні прийоми подачі матеріалу - лекції, відеофільми, ділові ігри, моделювання та ін. Програми можуть бути розроблені і реалізовані самою компанією або ж вона може вдатися до допомоги зовнішніх консультантів.

Внутрішньо фірмовий професійний стандарт (ВПС) повинен містити всю необхідну інформацію, що дає уявлення про те, якими мають бути моряки в даній компанії. Перевагою ВПС є поєднання всіх вимог компанії в одному, наочному документі, коли ще при влаштуванні на роботу члени екіпажу знають, які види робіт будуть виконувати на робочому місці.

Система підтримки рівня професійної майстерності в екіпажах повинна постійно вдосконалюватися шляхом коригування внутрішніх професійних стандартів через механізм сертифікації та оцінки рівня професійного знання фахівців. Стандарти дозволяють:

- розробляти навчальні програми та матеріали для використання в освітніх установах;

- розробити системи оцінок, які гарантують, що професійні знання и навички відповідають професійним стандартам;

- розробити систему сертифікації, що підтверджує відповідність професійним стандартам.

Сертифікація повинна носити обов'язковий характер и проводитись або при переході на нову, вищу за рівнем посаду, або через певний період часу після проходження останньої сертифікації, а іiї значимість та престижність визначається конкретним змістом і практикою роботи.

Як показує досвід, результат сертифікації багато в чому залежить від компетенції експертів, основним завдання яких $\epsilon$ прийняття рішення про відповідність працівника нормативним вимогам. До експертів ставлять вимоги, пов'язані з особистісними духовноморальними якостями, що забезпечують їх здатність повноцінно и неупереджено виконувати функції експерта. Для цього необхідно забезпечення незалежності діяльності центрів сертифікації фахівців від усіх других зацікавлених структур.

\section{Висновки та перспектива подальшої роботи за даним напрямком}

Методичні засади розвитку системи управління екіпажем та компанією, обумовлені вимогами філософії тотального управління якістю та компетентністю персоналу:

- аналізу особливостей змісту праці екіпажу, фактори його надійності та поведінки в екстремальних умовах;

- поняття «практична група», як об'єднання членів екіпажу, що поєднує в собі всі позитивні моменти, характерні для формальних и неформальних груп;

- застосування «м'якої» системи управління персоналом;

- філософія TQM;

- основні області, які потребують найбільших змін в підходах при управлінні персоналом (найм, навчання і розвиток, оцінка професійних якостей, винагорода);

- поняття початкової та придбаної компетентності;

- потреба в навчанні та принципи додаткової потреби в навчанні.

\section{ЛІТЕРАТУРА}

1. Резолюція А.741(18) Прийнято 4 листопада 1993 року Міжнародний кодекс з управління безпечною експлуатацією судів та запобіганням забруднення (Міжнародний кодекс 3 управління безпекою (МКУБ) / Електронний ресурс. [Режим доступу]: https://zakon.rada.gov.ua/laws/show/995_304?lang=uk\#Text (Дата запиту: 15.10.2021). 
2. Циркуляр MSC 829, Інструкції щодо застосування формальної оцінки безпеки в процесі формування правил / Електронний ресурс. [Режим доступу]: https://wwwcdn.imo.org/localresources/en/OurWork/HumanElement/Documents/MSC-

MEPC.2-Circ.12-Rev.2\%20-

\%20Revised\%20Guidelines\%20For\%20Formal\%20Safety\%20Assessment\%20(Fsa)For\%20

Use\%20In\%20The\%20Imo\%20Rule-Making\%20Proces...\%20(Secretariat).pdf (Дата запиту: 17.10.2021).

3. Chengi Kuo Managing ship safety in the 21 st century Lloyd's Practical Shipping Guides 204 Pages / Published: 01/12/1998.

4. Kuo, C. Managing Ship Structural Development, SNAME Ship Structure symposium, 2000.

5. Pomeroy, R. V. Marine Risk Assessment - the ISM code and beyond, LRS Website.

6. Vassalos, Dracos Shaping ship safety - The shape of future, Marine Technology, April 1999.

7. Health \& Safety Executive (1997) Successful Health and Safety Management HS(G)65 HSE Books.

8. Арсеньєв Ю.М., Шелобаєв С.І., Давидова Т.Ю. Управління персоналом. Моделі керування. ЮНІТІ. 2005., 287 с.

9. Арсеньєв Ю.М., Шелобаєв С.І., Давидова Т.Ю. Управління персоналом. Технології. ЮHITI. 2005., 191 c.

10. Афонін І.В. Управління розвитком підприємства. Стратегічний менеджмент, інновації, інвестиції, ціни. Навчальний посібник. М.: Дашков та К. 2002, 380 с.

11. Біляцький Н.П. та ін. Управління персоналом. Навчальний посібник. Мінськ: ТОВ "Інтерпрессервіс"; УП "Екоперспектива". 2002, 350 с.

12. Веснін В.Р. Менеджмент персоналу Еліт-2000. 2003., 304 с.

13. Герасимов Б.М., Чумак В.Г., Яковлєва Н.Г. Менеджмент персоналу Фенікс. 2003., 447 с.

\section{REFERENCES}

1. Resolution A.741(18) Adopted on 4 November 1993 INTERNATIONA MANAGEMENT CODE FOR THE SAFE OPERATION OF SHIPS AND FOR POLLUTION PREVENTION (International Safety Management (ISM) Code) [Online]. Available: https://zakon.rada.gov.ua/laws/show/995_304?lang=uk\#Text [Accessed: Oct. 15, 2021].

2. MSC Circular 829, Guidelines for application of Formal Safety Assessment in the rule making process [Online]. Available: https://wwwcdn.imo.org/localresources/en/OurWork/HumanElement/Documents/MSCMEPC.2-Circ.12-Rev.2\%20\%20Revised\%20Guidelines\%20For\%20Formal\%20Safety\%20Assessment\%20(Fsa)For\%20 Use\%20In\%20The\%20Imo\%20Rule-Making\%20Proces...\%20(Secretariat).pdf [Accessed: Oct. 15, 2021].

3. Chengi Kuo Managing ship safety in the 21 st century Lloyd's Practical Shipping Guides 204 Pages / Published: 01/12/1998.

4. Kuo, C. Managing Ship Structural Development, SNAME Ship Structure symposium, 2000.

5. Pomeroy, R. V. Marine Risk Assessment - the ISM code and beyond, LRS Website.

6. Vassalos, Dracos Shaping ship safety - The shape of future, Marine Technology, April 1999.

7. Health \& Safety Executive (1997) Successful Health and Safety Management HS(G)65 HSE Books. 
8. Arseniev Yu.M., Shelobaiev S.I., Davydova T.Yu. Upravlinnia personalom. Modeli keruvannia. YuNITI. 2005., $287 \mathrm{s.}$

9. Arseniev Yu.M., Shelobaiev S.I., Davydova T.Yu. Upravlinnia personalom. Tekhnolohii. YuNITI. 2005., $191 \mathrm{~s}$.

10. Afonin I.V. Upravlinnia rozvytkom pidpryiemstva. Stratehichnyi menedzhment, innovatsii, investytsii, tsiny. Navchalnyi posibnyk. M.: Dashkov ta K. 2002, 380 s.

11. Biliatskyi N.P. ta in. Upravlinnia personalom. Navchalnyi posibnyk. Minsk: TOV "Interpresservis"; UP "Ekoperspektyva". 2002, 350 s.

12. Vesnin V.R. Menedzhment personalu Elit-2000. 2003., 304 s.

13. Herasymov B.M., Chumak V.H., Yakovlieva N.H. Menedzhment personalu Feniks. 2003., 447 s. 